\title{
Characterisation of horseradish peroxidase immobilisation on an electrochemical biosensor by colorimetric and amperometric techniques
}

\author{
Aoife Morrin ${ }^{\mathrm{a}}$, Alicia Guzman ${ }^{\mathrm{b}}$, Anthony J. Killard ${ }^{\mathrm{a}}$, Jose M. Pingarron ${ }^{\mathrm{b}}$, Malcolm \\ R. Smyth ${ }^{\mathrm{a}, *}$ \\ a School of Chemical Sciences, Dublin City University, Dublin 9, Ireland \\ ${ }^{\mathrm{b}}$ Department Quimica Analitica, Universidad Complutense de Madrid, Ciudad Universitaria, 28040 Madrid, Spain \\ Received 13 March 2002; received in revised form 16 September 2002; accepted 20 September 2002
}

\begin{abstract}
This study presents the use of complementary colorimetric and amperometric techniques to measure the quantity of protein or enzyme immobilised onto a carbon paste electrode modified with a layer of electrodeposited polyaniline. By applying a solution of bovine serum albumin at $0.75 \mathrm{mg} / \mathrm{ml}$, efficient blocking of the electrode from electroactive species in the bulk solution could be achieved. When the horseradish peroxidase was immobilised on the electrode, optimal amperometric responses from hydrogen peroxide reduction were achieved at approximately the same concentration. The mass of enzyme immobilised at this solution concentration was determined by a colorimetric enzyme assay to be equivalent to the formation of a protein monolayer. Under these conditions, amperometric responses from the immobilised layer are maximised and non-specific bulk solution interactions are minimised. At higher immobilised protein concentrations, diminished amperometric responses may be due to inhibited diffusion of hydrogen peroxide to enzyme which is in electronic communication with the electrode surface, or impeded electron transfer.
\end{abstract}

Keywords: Horseradish peroxidase; Enzyme immobilisation; Screen-printed electrode; Polyaniline; Amperometry; Colorimetric enzyme assay

\section{Introduction}

The high selectivity of antibody molecules for their corresponding antigens has been widely exploited for analytical purposes mainly as enzyme-linked immunosorbent assays (Tijssen, 1985). Immunosensors - the logical development of immunoassays - combines the specificity provided by the molecular recognition of antibodies towards specific antigens, with a transducer to produce a physical signal proportional to the target analyte concentration. The most widely reported methods of transduction are optical (Skladal et al., 1999; Koch et al., 2000) and electrochemical (Pritchard et al., 1995; Padeste et al. 1998).

\footnotetext{
* Corresponding author. Tel.: +353-1-700-5508; fax: +353-1-7005503.

E-mail address: malcolm.smyth@dcu.ie (M.R. Smyth).
}

Immunosensors traditionally incorporate washing and separation steps before signal detection. This complexity, along with insufficient stability and reproducibility of the various interfaces contained within the sensor has prevented commercialisation. Although optical biosensors are commercially available, they are expensive and complex. Electrochemical methods have so far offered the best prospects for cheap mass production, due to simplified instrumentation and methodology.

An amperometric biosensor has been developed, incorporating the electroactive polymer, polyaniline (PANI), which undergoes redox cycling, and can couple electrons directly from the enzyme active site, to the electrode surface (Killard et al., 1999). Construction of this sensor was achieved by electropolymerisation of polyvinylsulphonate (PVS)-doped aniline onto the surface of a screen-printed carbon-paste electrode. Biomolecules could then be doped onto the surface of the 
polymer by electrostatic interactions with the polymer backbone. This effective biosensor format has examined the amperometric behaviour of immobilised horseradish peroxidase (HRP) (Iwuoha et al., 1997), and has since been extended to develop rapid, single-step separationfree immunosensors for real-time monitoring for biotin and atrazine. (Killard et al., 1999, 2001). This work is based on disposable single-use screen-printed electrodes.

A key component in a biosensor is the recognition molecule and its immobilisation. Methods for the immobilisation of biomolecules onto transducer surfaces include physisorption (Van Es et al., 2001), covalent linking, coupling via streptavidin-biotin linkage ( $\mathrm{Pa}-$ deste et al., 1998) and in the case of this system, adsorption by electrostatic forces (Killard et al., 1999). In this instance, protein molecules become electrostatically attached to the backbone of the electroactive polymer polyaniline by application of an oxidising potential. Previous studies had shown that a protein concentration of $0.5-0.75 \mathrm{mg} / \mathrm{ml}$ yielded the optimal amperometric signals encountered (Killard et al., 2001). However, it was not clear why this concentration yielded the optimum responses from the sensor. In addition, the absence of the necessity for blocking or separation steps was not fully understood.

This study investigates the process of protein immobilisation using amperometric and colorimetric techniques. This demonstrates that under optimal immobilisation conditions, a protein monolayer may be formed at the electrode surface. In the case of enzymes such as HRP, this provides simultaneous blocking of the electrode surface from bulk solution interactions as well as yielding optimal electron transfer properties.

\section{Experimental}

\subsection{Materials}

HRP (1100 and $1310 \mathrm{U} / \mathrm{mg}$, P8672); bovine serum albumin (BSA, A-7906); and 2,2'-azino-bis(3-ethylbenzthiazoline-6-sulphonic acid) (ABTS, A1888) were purchased from Sigma-Aldrich (Poole, Dorset, UK). Aniline was purchased from Aldrich (13 293-4), vacuum distilled and stored frozen under nitrogen. 30\% (v/v) hydrogen peroxide solution was purchased from Merck. PVS (27 842-4) was purchased from Aldrich.

\subsection{Buffers and solutions}

All electrochemical measurements were carried out in phosphate buffered saline (PBS), $(0.1 \mathrm{M}$ phosphate, $0.137 \mathrm{M} \mathrm{NaCl}$ and $2.7 \mathrm{mM} \mathrm{KCl}$ ), $\mathrm{pH}$ 6.8. All colorimetric assays were carried out in $10 \mathrm{mM}$ phosphate buffer, $\left(0.33 \mathrm{mM} \mathrm{KH}_{2} \mathrm{PO}_{4}\right.$ and $\left.0.66 \mathrm{mM} \mathrm{Na}_{2} \mathrm{HPO}_{4}\right), \mathrm{pH}$
7.0. The ABTS buffer was $200 \mathrm{mM}$ dihydrogen phosphate and $100 \mathrm{mM}$ citric acid, and adjusted to $\mathrm{pH} 5.5$ using concentrated $\mathrm{NaOH}$.

\subsection{Instrumentation}

All electrochemical protocols were performed on a BAS100/W electrochemical analyser with BAS100/W software, using either cyclic voltammetry or time-based amperometric modes. Electrochemical batch and flow cells were constructed according to Killard et al. (1999). They were composed of polycarbonate, and both cells incorporated $\mathrm{Ag} / \mathrm{AgCl}$ reference and platinum auxiliary electrodes. Nunc Maxisorp microtiter plates (Biosciences, Ireland) were used for the colorimetric assays in conjunction with an ICN Flow Titertek ${ }^{\circledR}$ Multiskan PLUS microplate reader (Medical Supply Co., Ireland).

\subsection{Screen-printed electrode fabrication}

Electrodes were screen-printed onto a polyester (PET) substrate. Screen-printing was performed on a semiautomated DEK 248. Nylon mesh screens were used. Initially, a silver conductive layer (screen mesh size 174TT and Lifescan silver ink, donated by Inverness Medical Limited) was applied with a curing temperature of $70{ }^{\circ} \mathrm{C}$ for $6 \mathrm{~min}$, followed by a carbon ink (screen mesh size 156TT and Ultra ink, donated by Inverness Medical Limited) sensor layer with curing at $70{ }^{\circ} \mathrm{C}$ for $13 \mathrm{~min}$. A non-conducting insulation layer (screen mesh size 230TT and Ercon insulation ink, donated by Inverness Medical Limited) was then applied over the surface, which defined the working electrode area to be $9 \mathrm{~mm}^{2}$.

\subsection{Electrode preparation}

The screen-printed electrodes were cut from the PET sheet leaving excess width on either side to a width of 14 $\mathrm{mm}$.

\subsubsection{Polymerisation of aniline on the electrode surface}

A mixture of $7.8 \mathrm{ml} 1 \mathrm{M} \mathrm{HCl}, 186 \mu \mathrm{l}$ aniline and $2 \mathrm{ml}$ polyvinylsulphonate was degassed under nitrogen for 10 min. Aniline was polymerised onto the surface of the working electrode using cyclic voltammetry. A platinum mesh auxiliary and a $\mathrm{Ag} / \mathrm{AgCl}$ reference electrode were used. Seven voltammetric cycles were required between -500 and $1100 \mathrm{mV}$ versus $\mathrm{Ag} / \mathrm{AgCl}$ electrode at 100 $\mathrm{mV} / \mathrm{s}$, and sensitivity at $1 \times 10^{-3} \mathrm{~A} / \mathrm{V}$ in order to reach the required PANI layer thickness.

\subsubsection{Immobilisation of protein}

Following polymerisation of aniline, the electrode was transferred to a $2 \mathrm{ml}$ batch cell. The surface of the polymer was reduced in $2 \mathrm{ml}$ of PBS (degassed for 10 
min under nitrogen) at $-500 \mathrm{mV}$ versus $\mathrm{Ag} / \mathrm{AgCl}$, sample interval of $500 \mathrm{~ms}$, over $1500 \mathrm{~s}$ at a sensitivity of $1 \times 10^{-4} \mathrm{~A} / \mathrm{V}$. Protein was prepared in PBS prior to use. Very quickly after reduction was complete, PBS buffer was removed from the cell and quickly replaced with the protein solution, not under stirring or degassing. Again quickly, oxidation was performed at $700 \mathrm{mV}$ versus $\mathrm{Ag} / \mathrm{AgCl}$ for $1500 \mathrm{~s}$. During this oxidation, the protein becomes electrostatically attached to the polymer surface. The protein solution was carefully recovered from the cell and re-stored for later use.

\subsection{Electroanalytical procedure}

After the immobilisation of protein, the electrode was transferred to a flow cell. Amperometric experiments were performed at $-100 \mathrm{mV}$ versus $\mathrm{Ag} / \mathrm{AgCl}$, with a sample interval of $500 \mathrm{~ms}$ and a sensitivity of $1 \times 10^{-4}$ A/V. PBS was passed over the surface of the electrode at a flow rate of $10 \mu \mathrm{l} / \mathrm{s}$. When a steady state was reached, appropriate solutions were passed over the surface of the electrode and the increase in catalytic current monitored.

\subsection{Blocking of the electrode surface with BSA}

A range of dilutions of BSA beginning at $10 \mathrm{mg} / \mathrm{ml}$ was prepared in PBS. These solutions were used for the immobilisation of BSA on the surface of the electrode according to Section 2.5 and a series of electrodes with different masses of BSA was prepared. An electroanalytical procedure was performed according to Section 2.5 where a solution of $\operatorname{HRP}(0.5 \mathrm{mg} / \mathrm{ml})$ and $\mathrm{H}_{2} \mathrm{O}_{2}(0.8$ $\mathrm{mM}$ ) in PBS was passed over the surface of each electrode.

\subsection{Optimisation of the mass of HRP on the electrode surface}

Dilutions of HRP beginning at $10 \mathrm{mg} / \mathrm{ml}$ were prepared in PBS. These solutions were used for the immobilisation of HRP onto the surface of a series of electrodes according to Section 2.5. The electroanalytical procedure was as described in Section 2.5 where a solution of $\mathrm{H}_{2} \mathrm{O}_{2}(0.8 \mathrm{mM})$ in PBS was passed over the surface of each electrode.

\subsection{Colorimetric enzyme assay}

Solutions of HRP in doubling dilutions beginning at $10 \mathrm{mg} / \mathrm{ml}$ were prepared in phosphate buffer, $\mathrm{pH} \mathrm{7,} \mathrm{for}$ use as a set of calibration standards. ABTS solution $(5.33 \mathrm{mg} / \mathrm{ml})$ was prepared, containing $\mathrm{H}_{2} \mathrm{O}_{2}(0.3 \mathrm{mM})$. $20 \mu \mathrm{l}$ of the HRP solutions were transferred to the wells of a microtitre plate with $180 \mu \mathrm{l}$ of the ABTS solution. The plate was covered with laboratory film, left in the dark for 35 min and then the absorbance read at 620 nm.

Colorimetric enzyme assays were performed on the surfaces of the screen-printed electrodes according to a similar protocol. In this instance, HRP-immobilised electrodes, prepared according to Section 2.4, were placed in the well of the microtitre plate along with 20 $\mu 1$ phosphate buffer to replace the HRP solutions in the calibration standards.

\section{Results and discussion}

\subsection{Dependence of sensor response on protein concentration}

Variations of this type of PANI-modified electrode surface with both enzyme and antibody have previously been studied (Killard et al., 2001). It was noted that in order to yield maximum current responses, the optimal concentration of enzyme or antibody to use in situ was found to be approximately $0.5 \mathrm{mg} / \mathrm{ml}$ for a screenprinted carbon paste electrode (geometric area: 7.07 $\mathrm{mm}^{2}$ ). However, the reason for this result was not fully elucidated at this time.

In order to assess what the mode of action was for this system, PANI/PVS electrodes were modified with a range of concentrations of BSA and the reaction between HRP and $\mathrm{H}_{2} \mathrm{O}_{2}$ present in the bulk solution was monitored. HRP is a haeme-containing glycoprotein that is capable of the catalytic reduction of hydrogen peroxide substrate. This induces a catalytic current due to the electrochemical reduction of HRP I and HRP II, which are, respectively, the two and one electron states higher than the native HRP resting state. Varying concentrations of HRP were used to modify the electrode surface, and its response to hydrogen peroxide was noted (Fig. 1). It was found that, the mass of

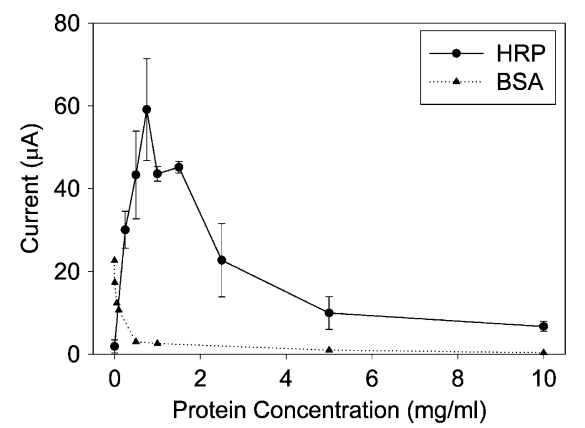

Fig. 1. Dependence of sensor response on the concentration of protein used for immobilisation. Amperometric responses increased as a function of concentration of HRP up to $0.75 \mathrm{mg} / \mathrm{ml}(n=3)$. Above this concentration the responses decreased (solid line). Concentrations of BSA immobilised were found to be inversely proportional to the amperometric responses from $\mathrm{HRP}$ and $\mathrm{H}_{2} \mathrm{O}_{2}$ in bulk solution (dotted line) $(n=1)$. 

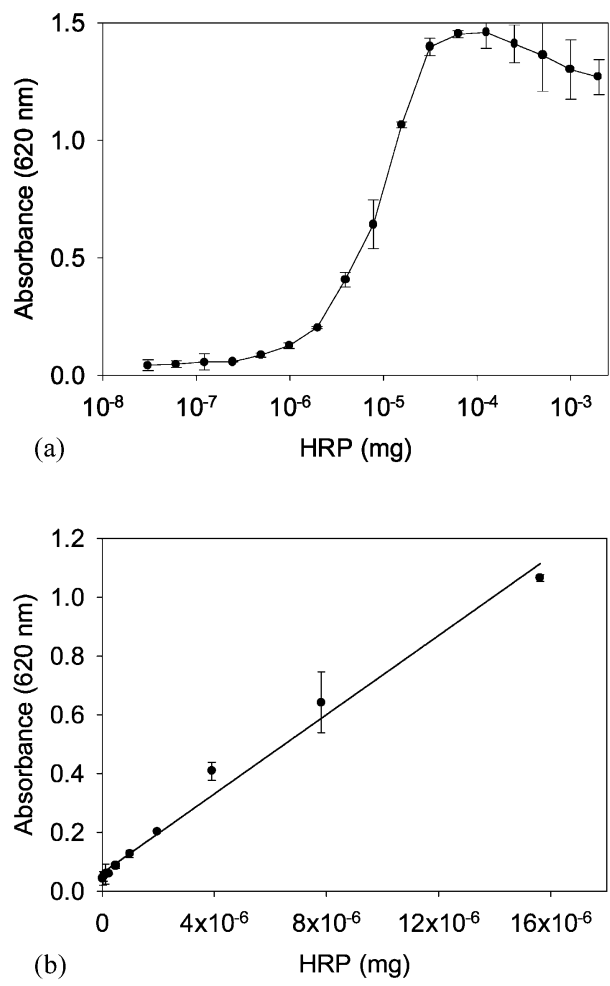

Fig. 2. Colorimetric HRP calibration assay $(n=3)$. (a) Absorbance $(620 \mathrm{~nm})$ versus mass of HRP over a range from 0 to $0.002 \mathrm{mg}$ (logarithmic scale). (b) Linear region of assay from 0 to $1.6 \times 10^{-5} \mathrm{mg}$ $\left(y=67364 x+0.0614, r^{2}=0.9871\right)$.

immobilised BSA was inversely proportional to the electrochemical responses from $\mathrm{HRP}$ and $\mathrm{H}_{2} \mathrm{O}_{2}$ in bulk solution. When HRP was immobilised on the electrode surface at various concentrations, amperometric responses generated by $\mathrm{H}_{2} \mathrm{O}_{2}$ in the bulk solution peaked at $0.75 \mathrm{mg} / \mathrm{ml}$, and diminished significantly above this, but decreased more gradually at lower concentrations.

These data seem to suggest that this critical concentration of approximately $0.75 \mathrm{mg} / \mathrm{ml}$ allowed for the effective blocking of the electrode surface from bulk solution interactions, while also providing optimal amperometric response from immobilised enzyme.

\subsection{Determination of the mass of protein immobilised to the electrode surface}

It is important to note that for a given concentration of protein used for immobilisation, a mass per unit area becomes electrostatically attached to the polymer-modified electrode during the immobilisation procedure. However, until now, the relationship between concentration and mass had not been established. Protein mass measurements were made by carrying out a set of colorimetric enzyme assays specific for HRP. The purpose of using an enzyme assay rather than a protein assay to measure the mass, was that protein assays were not sensitive enough to measure the small mass of protein attached to the electrode surface, whereas enzyme-based techniques could result in signal amplification over time. The substrate used was ABTS with $\mathrm{H}_{2} \mathrm{O}_{2}$, which yields a soluble blue-green product in the presence of HRP.

The kinetics of peroxidase with ABTS as a chromogen are relatively slow, allowing a reasonable time frame during which the colour can equilibrate, even at high concentrations of HRP. A calibration assay was carried out on HRP in solution according to Section 2.8, and a linear relationship was observed between 0 and $8 \times 10^{-5}$ $\mathrm{mg} / \mathrm{ml}$ (or between the masses of 0 and $1.6 \times 10^{-5} \mathrm{mg}$ ) (Fig. 2a and b). The assay was then carried out on the surfaces of the HRP-modified electrodes. All electrodes were washed extensively in PBS before the assay. A logarithmic relationship for this electrode assay was observed between concentrations of 0.00625 and 0.063 $\mathrm{mg} / \mathrm{ml}$ and was linearised (Fig. 3a and b). The linear segments of these curves were used for further analysis (Fig. 2b and Fig. 3b).

A correlation between protein mass and protein concentration could now be deduced by combining these two sets of data as absorbances corresponding to a concentration of HRP used during immobilisation could be related to a mass of HRP present on the electrode surface. Once this relationship was established, relevant information could be deduced by extrapolation (Fig. 4). This is the first time, to our knowledge, that this method for calculating the mass of protein on the polymer-modified electrode surface has been reported. This equation was calculated to be:

Mass of HRP immobilised

$$
=1.4521 \times 10^{-5} \log [\mathrm{HRP}]+3.375 \times 10^{-5}
$$

where $[\mathrm{HRP}]$ is the concentration of HRP used for immobilisation.

By converting the mass of HRP to molecules (based on a molecular weight of $44000 \mathrm{Da}$ ), the equation becomes:

No. of molecules of HRP

$$
=1.9845 \times 10^{11} \log [\mathrm{HRP}]+4.6097 \times 10^{11}
$$

By substituting [HRP] with the optimum protein concentration of $0.75 \mathrm{mg} / \mathrm{ml}$ (Fig. 1), then the number of molecules of HRP that are immobilised on the surface of the electrode would be $4.3618 \times 10^{11}$, according to Eq. (2).

Proteins such as antibodies and enzymes often have to be immobilised such that they retain their biological activity. Their large size and necessary accessibility to interact with other molecules usually requires sufficient spatial separation of their binding and active sites. Assuming the reported data to be correct, the next step was to elucidate the type of surface coverage being 

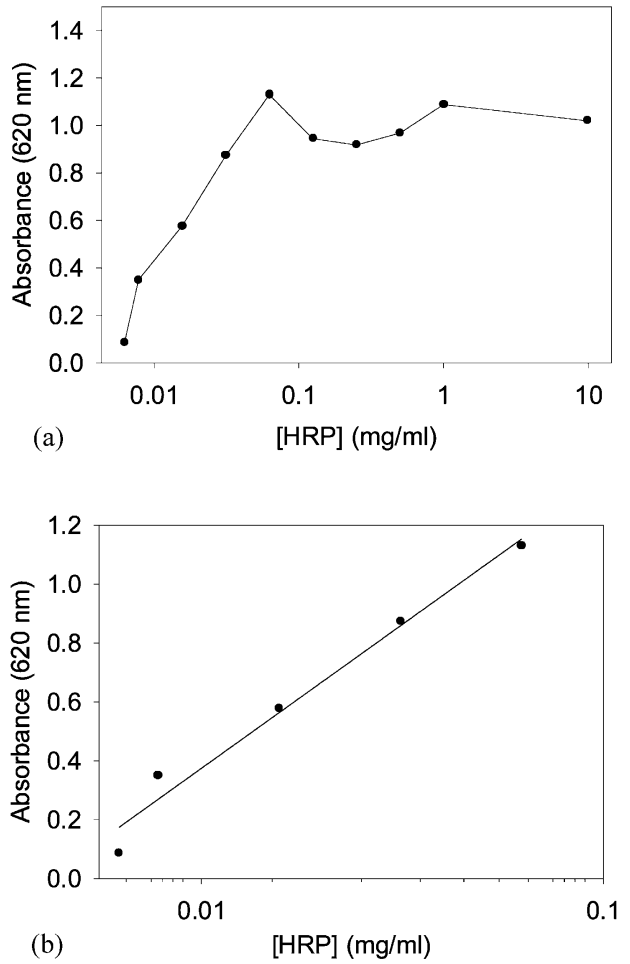

Fig. 3. Colorimetric enzyme assay of HRP-modified electrodes $(n=1)$. (a) Absorbance $(620 \mathrm{~nm})$ of HRP-modified electrodes from 0 to $10 \mathrm{mg} /$ $\mathrm{ml}$. (b) Linear region of assay from 0.00625 to $0.063 \mathrm{mg} / \mathrm{ml}$ ( $y=$ $\left.0.9782 \log x+2.3305, r^{2}=0.9777\right)$.

obtained at the optimum protein concentration using this electrochemical immobilisation technique. The number of molecules of HRP necessary to form a monolayer on the surface of these electrodes was calculated to be $4.237 \times 10^{11}$ molecules, where the radius of HRP was $26 \AA$, and the polymer-modified electrode area was estimated to be $9 \times 10^{-6} \mathrm{~m}^{2}$, assuming an ideal flat two-dimensional electrode surface.

The theoretical number of molecules of HRP required to form a monolayer at this surface can be compared to the number of molecules immobilised at optimum concentration. It would appear that at this concentration, a monolayer of protein is formed at the electrode surface. However, there are factors that may have introduced errors in both the methodology and the calculations. Regarding methodology, significant interelectrode variability brought about by variations during printing and polymer deposition could be a contributory factor. Within the calculations, a crude assumption was made about the surface area of the polymer-modified electrode and the microscopic topology of the polymer was not taken into account. In addition, the molecular weight of HRP in the literature varies from 40 to 44000 Da. However, the fact that the experimental data correlates so closely with the presence of a theoretical monolayer may explain the data seen in Fig. 1 and in previous work by Killard et al. (2001). At the optimal

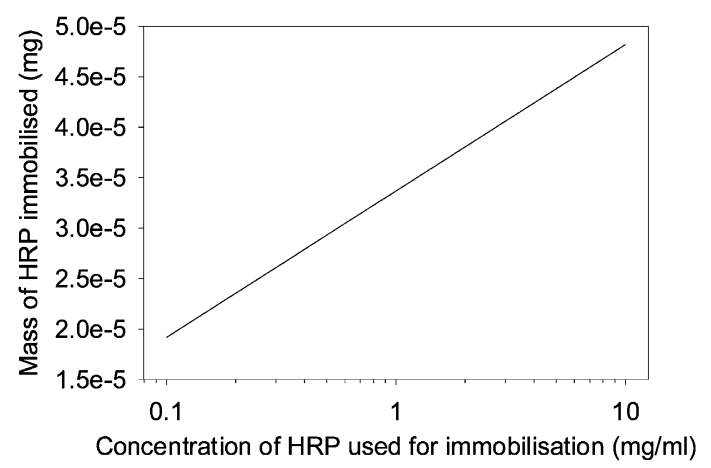

Fig. 4. Relationship between the concentration of HRP used during immobilisation and the mass of HRP present on the electrode surface. Graph obtained by combining graphs 2(b) and 3(b) $(y=1.4521 \times$ $\left.10^{-5} \log x+3.375 \times 10^{-5}, r^{2}=0.9871\right)$.

concentration of HRP $(0.75 \mathrm{mg} / \mathrm{ml})$, a monolayer, or very close to a monolayer appears to become immobilised at the electrode surface. At concentrations above this, steric hindrance or impeded charge transfer may result from crowding of the surface with multiple layers of protein, causing significantly diminished responses.

Further physical studies using techniques such as atomic force microscopy and scanning electron microscopy may clarify whether factors such as the microscopic structure of the electrode or steric hindrance of mis-orientated enzyme immobilised at the electrode surface result in a deviation from an ideal monolayer.

A discrepancy exists between the data for the electrochemical and colorimetric tests on immobilised HRP. This is that at concentrations higher than the optimal concentration, decreases in response were much more marked for the electrochemical data (Fig. 1) than for the colorimetric data (Fig. 3a). It may be the case that at concentrations above $0.75 \mathrm{mg} / \mathrm{ml}$, multiple protein layers become attached, and these layers inhibit diffusion of substrate to enzyme centres close to the electrode surface or catalyse it before diffusion can occur. This might result in a diminished electrochemical signal, as efficient electron transfer would not occur between these outer layers and the electrodes, whereas, in a colorimetric assay, these layers would all contribute to the signal produced (Fig. 5).

\section{Conclusions}

It appears that from indirect electrochemical and optical measurements, at optimal conditions, a monolayer of protein becomes deposited onto the polymer electrode, which simultaneously blocks non-specific responses from the bulk solution while providing efficient electronic interaction between the immobilised enzyme and the electrode as well as efficient mass transport of substrate to the enzyme. This understanding is essential for the application of this immobilisation 
(a)

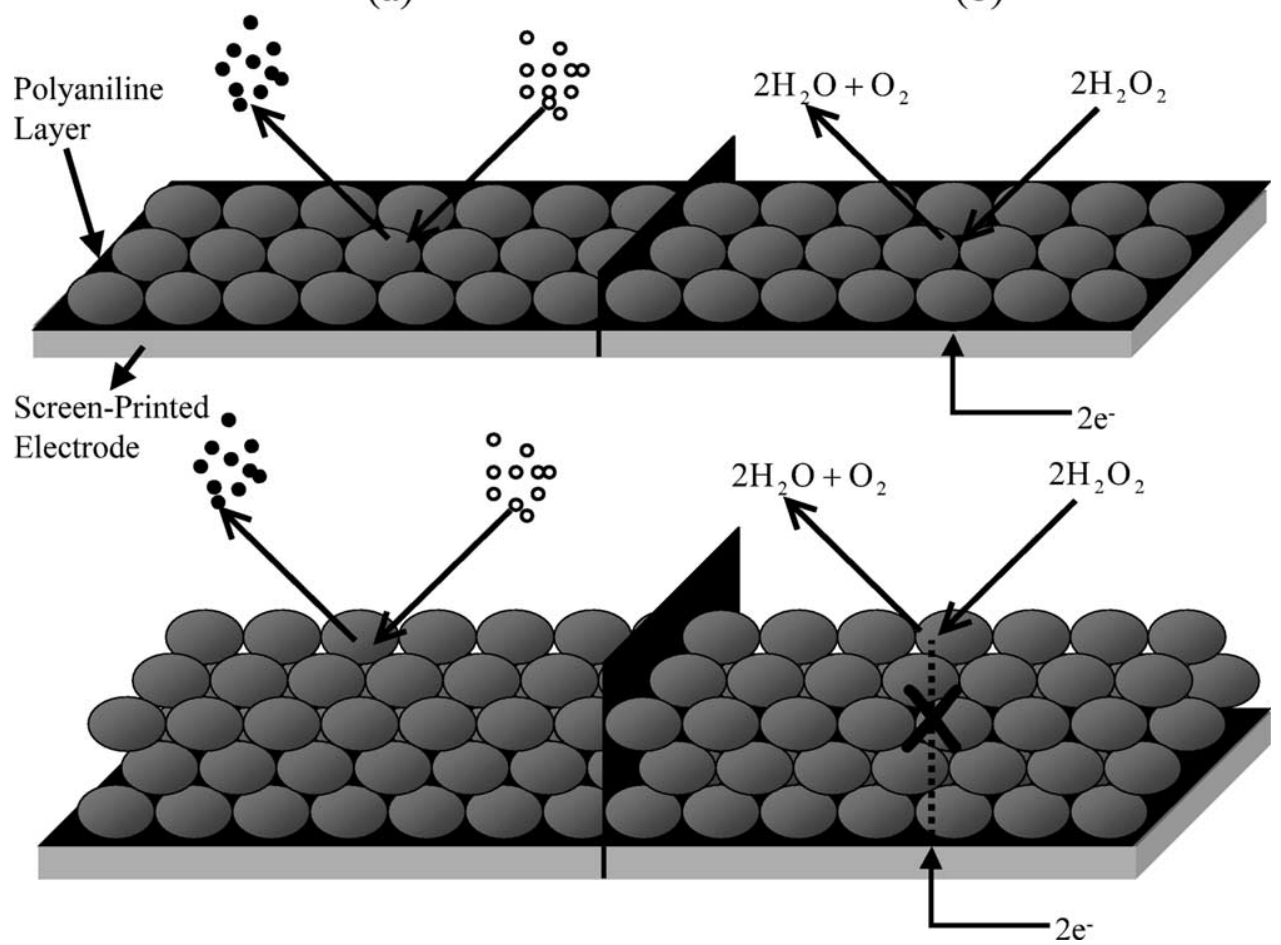

Fig. 5. Schematic diagram of the behaviour of the HRP-modified electrode surface for the colorimetric assay (a) and the amperometric assay (b). Large spheres represent HRP enzyme. Open and closed circles represent colourless and coloured substrate, respectively. The case for a monolayer is depicted (top), when maximum absorbance and amperometric response, respectively are observed. When multiple layers of protein are immobilised (bottom), little change in response for the colorimetric assay occurs. However this results in a significant decrease in amperometric response.

technique in enzyme and antibody biosensor applications.

\section{Acknowledgements}

The authors gratefully acknowledge the financial support and the supply of reagents from Inverness Medical Limited; and the financial assistance provided by the Royal Society of Chemistry and Enterprise Ireland. The authors are also grateful to Dr Ciaran Fagan (DCU) for advice during this work.

\section{References}

Iwuoha, E.I., Villaverde, D.S., Garcia, N.P., Smyth, M.R., Pingarron, J.M., 1997. Reactivities of organic phase biosensors. 2. The amperometric behaviour of horseradish peroxidase immobilised on a platinum electrode modified with an electrosynthetic polyaniline film. Biosensors Bioelectron. 12 (8), 749-761.

Killard, A.J., Zhang, S., Zhao, H., John, R., Iwuoha, E.I., Smyth, M.R., 1999. Development of an electrochemical flow injection immunoassay (FIIA) for the real-time monitoring of biospecific interactions. Anal. Chim. Acta 400 (2), 109-119.

Killard, A.J., Micheli, L., Grennan, K., Franek, M., Kolar, V., Moscone, D., Palchetti, I., Smyth, M.R., 2001. Amperometric separation-free immunosensor for real-time environmental monitoring. Anal. Chim. Acta 427 (2), 173-180.

Koch, S., Wolf, H., Danapel, C., Feller, K.A., 2000. Optical flow-cell multichannel immunosensor for the detection of biological warfare agents. Biosensors Bioelectron. 14 (10), 779-784.

Padeste, C., Grubelnik, A., Tiefenauer, L., 1998. Amperometric immunosensing using microperoxidase MP-11 antibody conjugates. Anal. Chim. Acta 374 (2), 167-176.

Pritchard, D.J., Morgan, H., Cooper, J.M., 1995. Simultaneous determination of follicle stimulating hormone and luteinising hormone using a multianalyte immunosensor. Anal. Chim. Acta 310 (2), 251-256.

Skladal, P., Deng, A., Kolar, V., 1999. Resonant mirror-based optical immunosensor: application for the measurement of atrazine in soil. Anal. Chim. Acta 399 (1), 29-36.

Tijssen, P., 1985. Practice and Theory of Enzyme Immunoassays. Elsevier, Oxford.

Van Es, R.M., Setford, S.J., Blankwater, Y.J., Meijer, D., 2001. Detection of gentamicin in milk by immunoassay and flow injection analysis with electrochemical measurement. Anal. Chim. Acta 429 (1), 37-47. 